\title{
TACTICAL MEDICINE INSPIRING CIVILIAN RESCUE MEDICINE IN THE MANAGEMENT OF HAEMORRHAGE
}

\author{
Maciej Sip ${ }^{1,2}$, Bogdan Serniak ${ }^{2}$, Dariusz Rogozinski ${ }^{2}$, Rastislav Kosec ${ }^{3}$, Alias Zajo ${ }^{3}$, Stepan Vokaty ${ }^{4}$, \\ Thomas Bräutigam ${ }^{5}$, Piotr Krawczuk ${ }^{6}$, Bartosz Zawada ${ }^{7}$, Marek Dabrowski ${ }^{1,2}$ \\ 'Department of Medical Rescue, Chair of Emergency Medicine, Poznan University of Medical Sciences, Poznan, Poland \\ ${ }^{2}$ Polish Society of Medical Simulation, Poland \\ ${ }^{3}$ Police, Slovakia \\ ${ }^{4}$ Police, Czech Republic \\ ${ }^{5}$ Police, Germany \\ ${ }^{6}$ Department of Orthopaedics and Trauma Surgery, Provincial Hospital in Poznan, Poland \\ ${ }^{7}$ Journal Club, Poznan University of Medical Sciences, Poznan, Poland
}

\begin{abstract}
Accidents remain to be the most common cause of death amongst men of ages 10-39 and women of ages $5-24$. The sudden occurrence of simultaneous multiple events or a mass casualty event with many patients suffering severe injuries, including severe haemorrhage, requires emergency medical personnel to modify the algorithms, which dictate their actions. The military war mission in Iraq and Afghanistan brought many experiences, which were used and applied to guidelines, which are now used for the management of patients experiencing trauma in the civilian sector. The current trauma ITLS (International Trauma Life Support) guidelines suggest to use compression bands or haemostatic dressings in order to control bleeding in case of massive haemorrhage. An example of this recommendation being used can be seen in the regional paramedic station in Poznan, Poland, where each ambulance is outfitted with "rescue packages" to be used in the event of massive haemorrhage. This practice can also be seen in Great Britain as well as Germany, where local protocols recommend the use of medical equipment taken from tactical medicine. The use of such tools allows for achieving a greater chance of rapid and effective haemostatic control in the event of massive haemorrhaging. These tools allow for more efficient use of time at the scene of the event, reducing the time a patient spends at the scene, allowing more rapid transport to hospital and more specialised surgical support. Reducing the time spent at the scene of an event while carrying out important procedures such as stabilising the patient's airway, stopping haemorrhage and immobilising the patient, markedly improves the survival of trauma patients.
\end{abstract}

KEY WORDS: rescue medicine, tourniquet, haemorrhage, dressings, haemostatic agents

Disaster Emerg Med J 2018; 3(1): 15-21

\section{INTRODUCTION}

According to the World Health Organization, an accident is defined as a group of unintended external threats to human life, resulting from human activities, physical, chemical or environmental fac- tors [1]. Accidents are the most common cause of death amongst men of ages 10-39 as well as women of ages $5-24$. Yearly there are approximately 13,000 deaths resulting from accidents in Poland (statistic from the Central Statistical Agen- 
cy for 2014). According to the Polish Police force, 33,664 traffic accidents were reported in 2016, with 3026 deaths and 40,766 injured, with 12,109 of those resulting in serious injury [2]. According to the model of the European Association for the Prevention of Accidents and Safety Promotion, "EuroSafe", it can be estimated that in Poland during one year, 2.8 million citizens are injured in accidents, with 384,000 injured going to hospital and 192,000 people reporting permanent disability as a result of their injuries [3]. In recent years, another threat to public safety have become terrorist attacks, and analysing only recent months, such events as "active shooters" have resulted in dozens of deaths and hundreds of injuries [4]. The goal of these attacks is to generate the highest amount of killed and injured. On 22 May 2017, the terrorist attack on the "Manchester Arena" during the concert of American singer Ariana Grande caused the death of 23 people and injured 119. On 3 June 2017 in London, terrorists drove their car into crowds of people on the London Bridge, and proceeded to attack people with knives at the nearby Borough Market, killing 8 people, and injuring 50. In Barcelona on 17 August 2017, a terrorist ran a van into a crowd of people killing 14, injuring 140 people and only a day later in Turku Finland, a man wielding a knife killed 2 people and injured 6 . The above examples of recent months only, show how much of a challenge these trauma patients are to emergency medical services, especially if they have suffered multiple complex injuries. Similarly to coronary and stroke events, severe injuries are conditions which are largely time-dependent, hence outcomes are often measured from the time of the injury to the time of definitive operative treatment, where it is important to master the ability to deal with these patients, especially for those suffering from massive haemorrhage. The urgency of providing quick yet effective control over the haemorrhage is supported by the extremely high mortality rate, where in trauma patients, haemorrhage can account for up to $80 \%$ of death, with most of them occurring within the first six hours of admission to hospital [5].

\section{PRIMARY SURVEY}

Each rescue event begins with a safety assessment, identifying any possible threats, followed by a general assessment of the scene. Both of these actions take place within the first few minutes of any rescue attempt. In accordance to the ITLS (International Trauma Life Support) guidelines, there are five crucial elements to this:

1. Standard precautions (personal protective equipment);

2. Safety at the scene of the incident;

3. Initial segregation of victims (specifying the number of victims);

4. Assessing if additional help or equipment is necessary;

5. Identification of the trauma mechanism.

The biggest threat to a rescuer, apart from contact with potentially contaminated materials such as bodily fluids or other biological materials, may be the very scene of the event they are responding to. This threat may come in the form of an automobile accident on a busy roadway, the scene of a crime with an active perpetrator or the scene of an explosion. According to ITLS guidelines, assessing scene safety is the first step of the primary survey where the next steps follow.

Initial Assessment - a general impression, meaning determining the victim's age, gender, body mass, general appearance, skin colour as well as looking for any obvious injuries or bleeding. In the case that massive bleeding is present, it is important to change from the usual algorithm of $A B C$ (Airway, Breathing, Circulation) to $C A B C$, where controlling and stopping haemorrhage becomes the first priority. Further actions revolve around assessing the victim's level of consciousness according to the AVPU scale, assessment of airway, breathing and circulation. In the event that there was a need to stop haemorrhage prior to assessment of $A B C$, this is the time to check the effectiveness of the applied bandages.

Trauma Survey - carried out in two ways depending on the mechanism of the trauma. If the mechanism is affecting the whole body or is unknown, a rapid survey of the entire body is necessary. If the mechanism of injury is known and has only affected one part of the body, a focused survey of the affected area is necessary.

Carrying out critical interventions such as securing airways, applying a tourniquet to stop haemorrhage, spinal immobilisation or stabilising foreign bodies, as well as deciding to transport the victim is the next priority [6].

\section{INJURIES AND HAEMORRHAGE}

The goal of the trauma survey, whether it be a global or local survey, is to quickly identify injuries, and 
depending on the nature of the trauma, they may have different characteristics:

- Open wounds - are an interruption of tissue continuity, with their size and depth being dependent on the force and objects involved. Lacerations, tears, crush injuries, stab wounds, as well as gunshot wounds, fall under this category of wounds;

- Penetrating wounds - arise from a foreign body entering and interrupting tissues, often damaging deep tissues and the structures along their path;

- Blunt injuries - arise as the result of a transfer of energy to tissues without disrupting their continuity;

- Isolated injuries and multifocal injuries;

- Multiorgan injuries - an injury to multiple organs in either the same or different parts of the body;

- Multiple injuries - serious injuries to at least two areas of the body [7].

An indispensable element of the rescue operation is knowledge of the potential blood loss depending on which part of the body has been affected, which may influence key actions and decisions regarding the control of such haemorrhage. In an adult victim, blood loss can be estimated depending on the organ or area injured (Tab. 1) [8].

The fundamental actions of a rescue attempt depend on the ability to assess vital signs, quickly locate wounds and potential haemorrhage and to provide the appropriate treatment. Superficial abrasions, minor cuts and burns are dealt with by placing a dressing made of gauze overtop of them. In the case of active haemorrhage, a compression bandage must be used, which consists of a dressing

Table 1. Estimated blood loss depending on
organ/body area affected
\begin{tabular}{|l|c|}
\hline \multicolumn{1}{|c|}{ Organ/area } & Estimated blood loss [ml] \\
\hline Pelvis & $3000-5000$ \\
\hline Spleen & 2000 \\
\hline Liver & 2000 \\
\hline Femoral fracture & $1500-2000$ \\
\hline Lungs & $1000-1500$ \\
\hline Tibia/fibula fracture & 1000 \\
\hline Humerus fracture & 800 \\
\hline Radius/ulna fracture & 400 \\
\hline Rib & 125 \\
\hline
\end{tabular}

affixed with an element, which may provide pressure (i.e. a rolled-up bandage). In the case of massive haemorrhage, amputation or severe crush injuries, which are difficult to control, a tourniquet may be used. One method of placing a tourniquet is to use a triangular cloth, which is placed proximally to the wound on an area of the body with a single bone (i.e. humerus or femur), $2-5 \mathrm{~cm}$ above the closest joint. After placing the tourniquet, it is crucial to record the time of its application [9]. In the event of active haemorrhage with no specialised equipment available, general purpose materials may be used, however this may be difficult and sometimes ineffective. From this arises the need to gain experience on the methods and materials used by different services, such as those used during the war missions in Iraq and Afghanistan. Extreme conditions forced these teams to modify standard procedures and find innovative ways to use different materials, thus further developing the field of tactical medicine.

\section{TACTICAL MEDICINE}

The priority of carrying out the combat mission, constantly changing conditions, as well as the possibility of enemy contact dictate the circumstances in which a victim may be examined. This order depends on the action zone, i.e. on the rescuer's safety. Tactical medicine can be characterised by three zones, with either the rescuer or victim being in them:

- Care Under Fire (CUF) - assistance provided while there is active enemy contact. The priority here should be to neutralise the enemy and to end the contact, falling under the philosophy of "the best medicine is good tactics";

- Tactical Field Care (TFC) - assistance provided on the battlefield. This zone is characterised as temporarily being a safe area, however it may return to an unsafe area and this back to the CUF zone;

- Tactical Evacuation (TE) - therapeutic processes are carried out on a level similar to ALS (Advanced Life Support) and ATLS (Advanced Trauma Life Support) if evacuation is carried out via MEV (Medical Evacuation Vehicle) or MEDEVAC/CASEVAC (aeroevacuation). In this zone, realisation of the tactical mission is of the highest priority, and must be prioritised before performing any other procedures [10].

In tactical rescue medicine a great deal of attention is given to the reversible causes of soldier's 
death, where apart from haemorrhage (which accounts for $90 \%$ of deaths), respiratory issues, such as pneumothorax, cause $7 \%$ of deaths and lack of airway patency accounts for $3 \%$ of deaths. Up to $60 \%$ of avoidable deaths on the battlefield are from severe haemorrhage from the extremities as a result of IEDs (Improvised Explosive Devices) [11]. During the combat missions carried out in Afghanistan by the Canadian Army from January 2016 to April 2018,73 soldiers died. The primary cause of death was haemorrhage from gunshot wounds and vehicular collisions [12]. Thus the order of the rescuer's procedures is carried out according to the scheme of SCABC (Safety-Control Bleeding-Airway-Breathing-Circulation), which according to the Tactical Combat Casualty Care (TCCC) guidelines is modified and called S-MARCHE (Safety, Massive Bleeding, Airway, Respiratory Management, Circulation, Hypothermia/Head Injury, Everything else/Eye Injury) [13].

Once in a safe setting, haemorrhage on a battlefield forces the rescuer to perform multiple tasks simultaneously, such as administering antibiotics, providing analgesia and counteracting progressive hypovolemic shock by administering tranexamic acid and blood substitutes in an attempt to refill the vascular bed. An alternative route of administering different types of fluids in the safe zone is the intraosseous infusion system named FAST [14].

The ability to help oneself, when they are left alone to fight, get out of a dangerous zone or provide medical assistance in the form of a tourniquet, forces one to establish quick control of haemorrhage utilising the "high and tight" method.

If the assistance is being provided to a victim in a relatively safe zone, it is important to first visualise the extremities if they are the source of haemorrhage and to swiftly place a tourniquet above the proximal edge of the wound $(5-7.5 \mathrm{~cm}$ above), making sure to never place a tourniquet on a joint. In the event of massive haemorrhage, which is unable to be controlled, CAT (Combat Application Tourniquet - North American Rescue, USA) (Fig. 1) or SOFTT-W (Special Operations Forces Tactical-Tourniquet Wide - Tactical Medical Solutions, USA) devices may be used. These tourniquets are certified by the manufacturers to be effective even in area with two bones (the forearm or calf). The high efficacy rates of tourniquets are confirmed by Kragh et al., who stated that tourniquets had a direct influence on survival rates in $87 \%$ of victims studied $(p<0.001)$ and prevented haemorrhagic shock

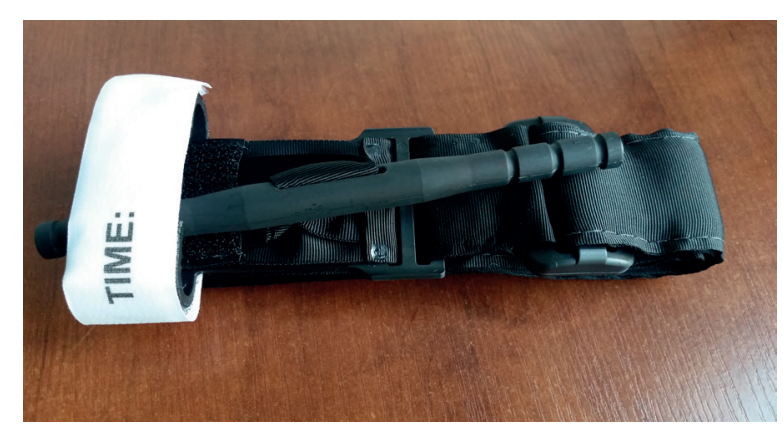

FIGURE 1. Combat Application Tourniquet

in $90 \%$ of victims $(p<0.001)$ [15]. When studying tourniquets, it is important to recall the ones which eliminate loose fitting tourniquets by way of a tape locking buckles (SAM XT Extremity Tourniquet - SamMedical, USA). Another approach to control haemorrhage are haemostatic agents. These agents are used while packing the wounds, and aim to fill the wound with a sealed dressing in order to overcome the hydrostatic pressure of a bleeding vessel.

The key ingredients on which haemostatic agents are based on are: Chitosan (made from the shells of crustaceans), zeolite (a mineral) and coagulants. Haemostatic agents in the form of absorptive granules and a binder based on chitosan are able to coagulate blood and stop haemorrhage after 2-3 minutes of coming into contact with human plasma. These agents are most commonly in the form of gauze, such as: Celox Rapid and Celox Gauze (SamMedical, USA), Combat Gauze XL (Quik Clot, USA) (Fig. 2) and Chitogauze PRO (North American Rescue, USA) [16]. If agents such as these are unavailable and the site of haemorrhage does not allow for the use of a tourniquet, alternative methods and devices must be used.

In the event of arterial haemorrhage with the possibility of bleeding into the pelvis, CRoC (Combat Ready Clamp, Combat Medical Systems, USA) or JETT (Junctional Emergency Treatment Tool — North American Rescue, USA) compression clamps may be used, which offer the possibility to compress the pelvis from both sides. According to TCCC guidelines, $25 \%$ of haemorrhages originating from the pelvis cannot be controlled by the use of tourniquet or haemostatic agent. Injuries in inaccessible areas, injuries sustained from explosions or amputations close to the groin can be compressed by the use of pelvic tourniquets such as the SJT (SAM Junctional Tourniquet - SamMedical, USA). Control of haemorrhage from the femoral arteries in the abdominal cavity can 


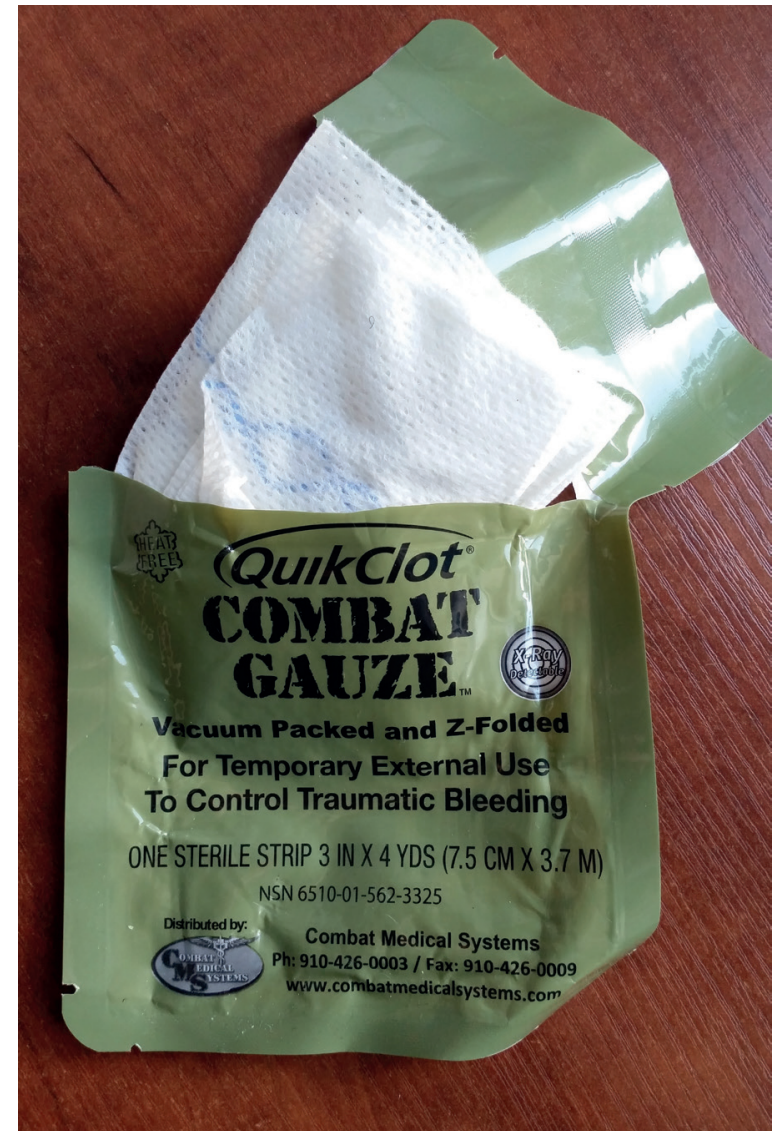

FIGURE 2. Quick Clot Combat Gauze

be achieved by placing a compression belt such as AAJT (Abdominal Aortic and Junctional Tourniquet - Compression Works LLC, USA), which compresses the abdominal aorta. Conventional bandages may also be employed in an effort to stop haemorrhage. The Olaes bandage (Tactical Medical Solutions, USA) (Fig. 3) is also known as the "three in one" bandage. There is a plastic element built into this bandage, which generates additional pressure at the site of the injury. Inside the bandage there is a gauze which has the purpose of packing the wound, as well as a plastic film to protect injuries to the chest wall. Another bandage frequently used in tactical medicine is The Emergency Bandage (First Care Products Ltd., Israel) (Fig. 4), also known as the Israeli bandage. The Israeli bandage is characterised by the built-in handle, which allows for more pressure to be put on a wound, hereby increasing the effectiveness of the bandage in stopping active bleeding.

\section{RESCUE MEDICINE}

The actions of emergency medical personnel in the civilian sector when dealing with trauma victims are

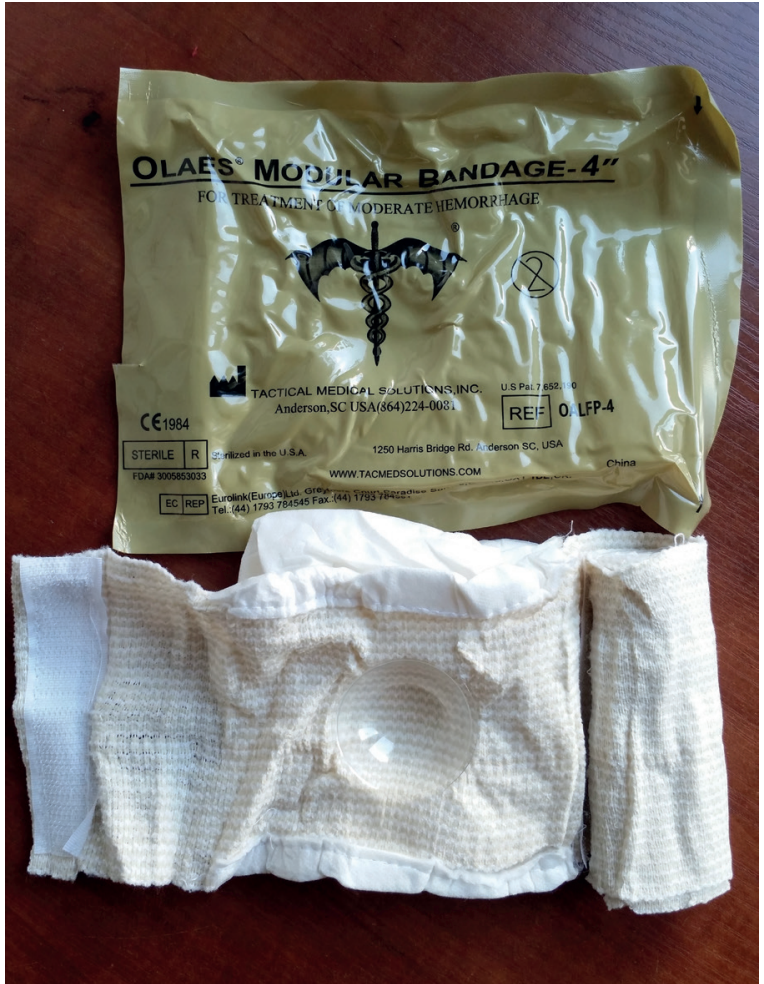

FIGURE 3. Individual dressing

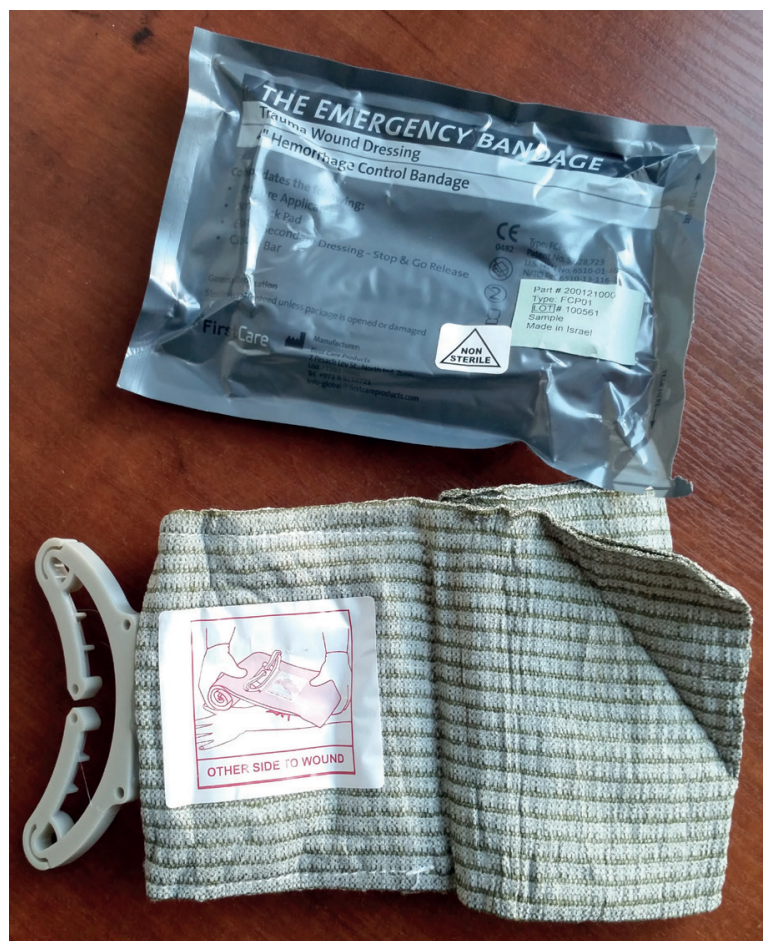

FIGURE 4. Emergency Israeli Bandage

dictated by the Trauma Life Support or Prehospital Trauma Life Support guidelines. These guidelines set out specific actions and interventions for specific situations and circumstances revolving around an 
injured patient. Civilian rescue medicine has seen many changes to its guidelines as a result of the evolution of tactical medicine and the experience, which have been gained from the battlefield. Procedures surrounding the management of a patient with massive external haemorrhage have been vastly enriched with new materials and equipment available for use. An example of this is in the case of massive haemorrhage in which bleeding cannot be controlled, and such tourniquets as the CAT, EMT pneumatic device (Emergency and Military Tourniquet — Delfi Medical Innovations Inc., Canada) may be utilised. An important note to remember in this case is that these devices' use should be limited to up to two hours (120 minutes). In the event that haemostasis may not be achieved with the use of a tourniquet or the haemorrhage is originating in a "difficult" to control area (neck, axilla or groin), the use of haemostatic agents such as Celox, QuikClot, Combat Gauze, HemCon (HemCon Medical Innovations Inc., Ireland) or TraumaDex (Medafor Inc,USA) may be considered [6].

Haemostatic agents should be treated as a tool to use in situations where other materials and methods are ineffective. The use of tactical medical devices in a civilian medical rescue is to the discretion of local protocols. An example of such protocols is the Regional Ambulance Station in Poznan, Poland, where all 24 ambulances are outfitted with so called "Rescue Packages" (Tab. 2).

In the case of the helicopters of the Air Rescue Service in Poland (22 permanent bases, 1 seasonal base), apart from the fundamental tools used to control haemorrhage, the helicopters are outfitted with the fallowing tactical medical equipment listed in Table 3.

In England, emergency medical services are also reliant on local protocols, where in different parts of the country the standards and outfitted equipment may differ. An example are the medical rescue teams servicing the north-west of London area, where the rescue package includes the following equipment listed in Table 4.

In comparison, emergency medical teams servicing Hamburg and Schleswig-Holstein (Northern Germany) are outfitted only with tourniquets for management of haemorrhage. The above examples illustrate the fact, that regardless of the ITLS recommendations of using tactical medical equipment, the outfitting of many emergency medical teams vastly vary.

\section{CONCLUSIONS}

The high rate of mortality in victims suffering from massive haemorrhage forces rescuers to carry out swift and effective interventions. The evolution of communication, construction infrastructure and industries is associated with the presence of risky behaviours, failure to comply with safety rules, and thus an increase in the number of accidents. Threats associated with terrorist attacks, explosives, shooters or attackers ramming a vehicle into pedestrians have the potential to injure dozens of people, and in these cases quick control over haemorrhages is the most important intervention, which may lead to increased survival. The ability for rescuers to maintain direct pressure on the wounds of multiple victims in the case where the amount of victims is not proportional to the amount of rescuers is often difficult and in many cases impossible. From this arises the need to use equipment from tactical medicine such as tourniquets, specialised bandages and haemostatic agents to guarantee safe and effective control over haemorrhage. The experi-

\begin{tabular}{|c|c|}
\hline Equipment & Quantity \\
\hline CAT tourniquet & 1 \\
\hline HemCon Hemostatic Bandage (ChitoGauze) & 1 \\
\hline Israeli tourniquet & 1 \\
\hline Sealing (occlusive) dressing & 2 \\
\hline Needle for chest puncture & 1 \\
\hline
\end{tabular}

Table 3. Outfitting of Air Rescue Service helicopters in Poland

\begin{tabular}{|l|c|}
\hline \multicolumn{1}{|c|}{ Equipment } & Quantity \\
\hline CAT tourniquet & 2 \\
\hline HemCon Hemostatic Bandage (ChitoGauze) & 1 \\
\hline Israeli tourniquet & 2 \\
\hline
\end{tabular}

Table 4. The composition of rescue medical outfitting in Great Britain

\section{Equipment}

\section{CAT/SOFTT-W tourniquets}

Blast Bandage Emergency Tactical Sterilized Trauma Dressing

Celox dressing

Large blast dressing

Olaes dressing

Russell Chest Seal 
ence of rescuers, doctors and military medics in civilian rescue medicine is a confirmation of the effectiveness of the tools and equipment from tactical medicine, which are employed in civilian medicine, giving the chance to save as many injured people as possible in the prehospital stage of treatment.

Conflict of interest: None declared.

\section{REFERENCES}

1. Międzynarodowa Klasyfikacja Chorób i Problemów Zdrowotnych rewizja 10. https://www.csioz.gov.pl/fileadmin/user_upload/Wytyczne/ statystyka/icd10tomi_56a8f5a554a18.pdf (29.01.2018).

2. http://statystyka.policja.pl/st/ruch-drogowy/76562,Wypadki-drogoweraporty-roczne.html (31.01.2018).

3. https://ec.europa.eu/health//sites/health/files/data_collection/docs/ idb_report_2013_en.pdf (31.01.2018).

4. Dąbrowski M, Sip M, Rogoziński D, et al. Active Shooters - how close are they? Disaster and Emergency Medicine Journal. 2017; 2(2): 69-73.

5. Spinella PC, Holocomb JB. Resiscitation and transfusion principles for traumatic hemorrhagic shock. Blood Rev. 2009; 23: 231-240.

6. Campbell JE. International Trauma Life Support. Ratownictwo przedszpitalne w urazach. Medycyna Praktyczna, Kraków 2015.

7. Guła P, Machała W. Postępowanie przedszpitalne w obrażeniach ciała. PZWL, Warszawa 2016.

8. Brzozowski R, Machała W, Guła P, et al. Ostra utrata krwi - co możemy zrobić w warunkach przedszpitalnych? Doświadczenia pola walki. Lekarz Wojskowy. 2014; 92(3): 248-254.
9. Witt M, Dąbrowska A, Dąbrowski M. Ratownictwo Medyczne. Kwalifikowana Pierwsza Pomoc. Wydaw. Nauk. Uniw. Med. im. K. Marcinkowskiego w Poznaniu, Poznań 2014: 181-206.

10. Dąbrowski M, Sanak T, Kluj P, et al. Specyfika udzielania pierwszej pomocy medycznej w warunkach bojowych w środowisku taktycznym na bazie standardu TCCC.Część I. Przyczyny zgonów oraz odmienności w postępowaniu z poszkodowanym w warunkach bojowych w środowisku taktycznym na bazie standardu TCCC. Anestezjologia i Ratownictwo. 2013; 7: 63-69.

11. Rush RM, Arrington ED. Recent advances and future directions in trauma care management of complex extremity injuries. Surg Clin North Am. 2012; 4: 987-1007.

12. Holcomb JB, McMullin NR, Pearse $L$, et al. Causes of death in U.S. Special Operations Forces in the global war on terrorism: 2001-2004. Ann Surg. 2007; 245(6): 986-991, doi: 10.1097/01. sla.0000259433.03754.98, indexed in Pubmed: 17522526.

13. Sanak T, Dąbrowski M, Kluj P, et al. Specyfika udzielania pierwszej pomocy medycznej w warunkach bojowych w środowisku taktycznym na bazie standardu TCCC. Część II. Zapewnienie hemostazy miejscowej podczas wykonywania zabiegów ratowniczych w fazie taktyczno-bojowej opieki nad poszkodowanym na bazie standardu TCCC. Anestezjologia i Ratownictwo. 2013; 7: 94-103.

14. Committee on Tactical Combat Casualty Care. Tactical Combat Casualty Care Guidelines. Washington: Government Printing Agency; 2012 September 17.

15. Kragh JF, Walters TJ, Baer DG. Survival with emergency tourniquet use to stop bleeding in major limb trauma. Ann Surgery. 2009; 294: 1-7.

16. Kheirabadi B. Evaluation of topical hemostatic agents for combat wound treatment. US Army Med Dep J. 2011: 25-37, indexed in Pubmed: 21607904. 